\title{
The Issue of Institutionalization of Political Parties in Post-soviet Georgia
}

\section{Maka Benashvili*}

\section{ARTICLE INFO}

Article history:

Accepted: October 302020.

Approved: December 152020.

\section{Keywords:}

Parties, Party Systems, Dominant Parties, Political Competition, Delegative Democracy, Presidentialism.

\begin{abstract}
A B S T R A C T
Political Parties are regarded as one of the main actors. They act as a mediator between the state and the citizens. Moreover, the proper functioning of strong party systems in the country guarantees the stability of the political system.

The stability of party systems is particularly important and relevant in relatively young democracies where state institutions are not fully established. A clear example of this is the countries of the post-Soviet space. Where the formation of party systems is encountered differently but with some similar difficulties, taking into account the experience and adapting it to the interests of the country is prominent and relevant for the Georgian reality.

Since the collapse of the Soviet Union, the most pressing issue in the world has been the observation of the development of post-socialist countries. During this period, political systems were also established in Eastern European countries and in the Caucasus region to allow non-communist parties seeking power to come to power. Institutionalization of the party system, which in the post-communist countries, has encountered considerable obstacles subsequently, Georgia is not an exception. However, it should be noted that compared to other countries, the process of institutionalization and transformation in Georgia has lasted a very long time. It is interesting how the political systems and parties of the post-socialist states went through the formation and what is the current state of their representation today. This is one of the main issues in this article.
\end{abstract}

(c) 2020 Published by the Institute for Development Studies, Sulkhan-Saba Orbeliani University.

\section{Introduction}

Political parties play a core role in building representative democracy in the modern state. It is the parties that represent the voice of the people. A healthy democratic environment has been created through inter-party relations and competition. The results achieved by the thorough work of political parties are one of the main indicators of public evaluation. Given that the nature of party

*Ph.D. Student, Georgian Technical University, Tbilisi, Georgia. 
politics exerts a noticeable influence on the democratization process, it is natural that Georgia will not be able to achieve a consolidated democracy without a proper foundation of the political party system.

After the collapse of the Soviet Union, the main challenge for Georgia was to strengthen the state structures and establish a stable democracy. A core factor in establishing a stable democracy is the level of development of political parties. It is interesting what the reason for the weak institutionalization of political parties in Georgia.

The multi-party system in Georgia does not have a long history, and this leads to frequent changes in the spectrum of parties. It is an interesting fact that about 300 parties are officially registered in Georgia, although very few of them are actively involved in political life. There is also a tendency for one dominant party to be the decision-maker.

This article presents the main and current problematic aspects of the political party system in Georgia, which in turn hinders the proper functioning of the system. The main aim of the paper is to present the transformation of the political party system of Georgia towards a growing democracy. It is interesting what the representation was in the parliaments of Georgia from 1990 until today. To achieve this goal, the paper analyzes the issue of party representation in the legislature. Specifically, this article offers the dynamics developed based on the research on the political parties participating in the parliamentary elections and their entry into the legislature.

Numerous studies on political parties have been conducted in the Georgian reality, however, I believe that in-depth analysis of the formation of the political party system and its accompanying challenges as Georgia, as a developing democracy, needs much more research. In order to determine what factors encourage weak institutionalization and why the system becomes dominant, a multitude of scientific analyzes are required, which will allow us to identify the crucial problematic aspects and identify ways to eliminate them. That is why I think my research is a kind of novelty that will be an indispensable source in terms of information. Using scientific methods, I will try to explain the cause-and-effect relationships and, as far as possible, present a picture that analyzes the problematic aspects of the Georgian party system.

\section{Literature Review}

The article accumulates and analyzes the analysis of scientific papers that are directly related to the research topic. Having read a number of papers while working on the article (Chiaramonte \& Emanuele. V. 2015; Darchashvili, 2020; ), I would like to point out that a large number of scholars believe that a stable and representative party system in post-communist countries is prime for the consolidation of a democratic regime. The authors formulate the four dimensions necessary for the institutionalization of the party system (Mainwaring \& Scully, 1995; Ibenskas \& Sikk, 2016; Lewis, 2007; Molder, 2013; Rohrschneider \& Whitefield, 2017). Interestingly, they primarily distinguish the degree of competition within the system. Since institutionalization in its content is essentially related to the issue of stability, we can consider this approach to be the easiest and most important to assess it. This theory is very interesting in my research because it presents the very criteria by which the degree of institutionalization of political party systems should be assessed. If we apply the criterion presented in the given theory to the Georgian reality, we will see clearly that in the Georgian reality there was almost no competition between the parties for years, for example, in 2003-2020 the dominance of one party within the Georgian party system was due to various objective circumstances. In Georgian 
reality, the very first dimension of mainstream and scale was neglected. This was probably one of the reasons for the weak institutionalization. The second and vital dimension, according to Mainwaring and Scale, is that in more institutionalized systems, parties have deeper roots in society and, conversely for most voters, strong ties to parties. The point is that in vital cases, good institutionalization means that the majority of voters are identified with the party and they vote solely based on their party values and programs. This dimension is also interesting for my research because it directly contradicts the issue of "personification", one of the controversial circumstances that characterize the Georgian political agenda and contributes to the weakness of institutionalization. In the third dimension, in more institutionalized systems, political parties agree on the legitimacy of parties. Legitimacy contributes to the stability of the party system and is, therefore, an essential component in assessing institutionalization. Finally, according to the fourth indicator, in more institutionalized systems, party organizations are not subject to the interests of an ambitious leader, they acquire their own status and value. This means not gathering voters around a particular leader in society, but uniting around values and interests. As we can see, for the above authors, a high level of institutionalization is primarily related to the stability of the system, which in turn requires the existence of certain conditions. First, it is competition, and then the depth of party roots in society. That is, how much the voter identifies himself with this or that party.

The four main dimensions proposed by Mainwaring and Scala once again reveal that the personification of Georgian politics, the absence of party competition, has created an unstable environment, and the latter in turn is the cause of a weakly institutionalized system.
Leadership and personalization became supreme during election results. Authors Crew and King called the process "the modernization of the modern election campaign" (Crewe \& King, 1994), This means that in highly developed industries, citizens make choices because of their commitment and belief in party programs, while in volatile systems, personalism plays a larger role in voting. The Georgian political reality itself is saturated with elements of personification; at the time of the elections, the figures of Gamsakhurdia, Shevardnadze, Saakashvili, and finally Ivanishvili were the ones who decided the election results. Accordingly, according to these two authors, a similar type of personalization is characteristic of unsustainable systems. It is clear that even for Crew and King alone, the Georgian political system is unsustainable, less institutionalized. Moreover, the authors also respond to the issue of populism, which enriches the Georgian political agenda. They say that populism and antipolitics are characteristic of an unsustainable system where individuals dominate and not party organizations.

With weak institutionalization, there is more uncertainty and doubt about the issue of election results, which weakens the democratic regime. The greater the probability of one party changing to another. There is a high probability that a person will be elected to a position based only on his / her characteristics. In turn, there are many examples in history when a high level of personification due to weak institutionalization was the path to authoritarianism. Weak institutionalization reduces communication between the public and the parties, which makes the issue of accountability problematic. Accountability on the part of the parties is the main condition for the existence of a democratic society. 


\section{JOURNAL OF DEVELOPMENT STUDIES}

\section{Research Methodology and Theoretical Framework}

The paper will use the theoretical framework of the work of Scott Mainwaring and Mariano Timothy on the institutionalization of parties (Mainwaring, 1999), where they develop two empirical arguments. The first is programmatic and ideological ties, a guarantee of stability between voters and parties, and the second ties between voters and parties are more personal in developing countries than in highly developed, industrial democracies. Interestingly, the authors' conclusion of these two empirical assertions, where they say that weak institutionalization negatively affects electoral accountability, weakly institutionalized electoral systems are more vulnerable and allow anti-party entities to come to power.

The paper is based on established research methods in political science. Qualitative analysis uses one type of research data analysis - content analysis. It includes a study of the literary material around the research topic. Also used is the method of comparative analysis, theories developed around the research problem, research results, and provisions that reflect the transformation and development of events and processes in this field, especially we use the method of studying documents and discussing the existing issue through comparative analysis.

\section{Institutionalization of Political Parties in Georgia}

There is a great deal of disagreement among scholars as to how to define the institutionalization of the party system. Huntington describes institutionalization as the process by which organizations and procedures achieve stability and acquire high values (Huntington, 1968).

There is no single universal definition in political theories of what institutionalization is and what the degree of institutionalization of parties implies. In economic theory, institutions create the rules of the game, while organizations are "players" within it (North, 1993). In this sense, political parties are organizations that should be developed within the system through institutionalization.

The development of party systems in Georgia has been greatly influenced by the presidential government, as power is concentrated in the hands of one person at a time. Georgia was established as a presidential republic in 1991. The 1992 parliamentary elections revealed 24 winning parties but failed to ensure electoral accountability and most of them did not even run in the subsequent elections. Unfortunately, with the intervention of radical forces, the government in Georgia was changed without elections. During Gamsakhurdia's rule in Georgia, the confrontation between alternative political forces overcame the election competition, and former allies confronted each other at gunpoint.

Georgia has continued its political life since 1995 under Shevardnadze. By this time, American-style governance in Georgia had been established as a strong presidential republic, as a semi-presidential republic was not considered an adequate form of government in the 1990s. During Shevardnadze's time, the opposition was weak and divided. Although the Georgian Citizens' Union has been challenged by many parties, a real alternative to the electorate has emerged within the former ruling party, the United National Movement. After the 2003 Rose Revolution, Mikheil Saakashvili, who came to power on February 6, 2004, gave the presidency even more powers under constitutional amendments. Under a strong presidential government, the president-elect party was in a dominant position, while the opposition parties were characterized by pragmatism and weakness. Weak parties in the opposition spectrum failed to offer Georgian society an effective alternative. 
In the 2012 parliamentary elections, the former ruling party joined the opposition and continued its political life and activities, of course, this was a great precedent in the process of establishing democratic political traditions in Georgia. The Georgian Dream coalition continued the tradition of governing the government with a majority. The decisive factor in this process was the factor of Bidzina Ivanishvili, around which the main opposition coalition was formed. Ensuring the democratic conduct of the 2016 parliamentary elections was crucial to maintaining and perpetuating the above trend.

While the 2016 pre-election environment raises expectations for the formation of a multi-party parliament and a coalition government, polarization persisted in the final stages of the election campaign, affecting voter attitudes. Thus, instead of a multiparty system, we had contours of a bipartisan system. The fact was that the qualified entities that remained outside Parliament failed to assess the resource capabilities of the two major parties and were unable to pool their resources into a single platform. For example, if the Free Democrats and the Republics united in a bloc, they would inevitably cross the electoral threshold. The other parties also had a resource for cooperation. The Alliance of Patriots of Georgia does not change the existing reality. The local success of a given political union is linked to a marginal trend that is situational and proves once again that society is tired of other marginalized parties, such as the Labor Party.

I would like to point out that the stability of political parties fighting for office is fundamentally important for democratic elections. The stability of the parties is especially important in the context of Georgia: the country's political system is being formed as a parliamentary government after the 2013 presidential elections. Moreover, after the 2016 parliamentary elections, there are discussions about new constitutional amendments that would allow delegates to Parliament and City Councils to elect a president. Parties play a more important role when parliament has more power. Therefore, Georgian democracy is inconceivable without strong and sustainable political parties that are guided by the values of consolidating democracy.

One of the main barriers to the formation of a multiparty system lies in the interdependence of the parties. Frequent changes in the electoral system hinder the formation and development of political organizations as viable organizations. The system cannot ensure equal representation of the political will of the voters in the parliament and even in the conditions of inadequate support of the voters, thanks to the majority, the electoral system makes possible the existence of a constitutional majority.

The latest constitutional changes in Georgia, which serve to increase democracy, provide for the formation of a multi-party legislature. There has been a change in the electoral system, which means that Georgia will move from a mixed electoral system to a fully proportional electoral system from 2024, and the 2020 parliamentary elections will be held again using a mixed electoral system (Organic Low of Georgia, Article 196.2).

\section{Discussion and Conclusion}

It has been a fact since 1990 that the number of subjects participating in all types of elections is increasing: 1. 1990. Participants 14 , represented in the government - 6 , of which proportionally - 2 (threshold - 4\%); 2 . 1992 participants - 36, represented in government - 24 in proportion ( $2 \%$ threshold); 3. 1995. Participants - 53, represented in government - 13; Out of proportion - 3 (5\% threshold); 4. 1999. Participants - 45, represented in the government -6 , of which proportionally - 3 ( $7 \%$ threshold); 5 . The results of the 2003 elections were annulled; 6. 2004 


\section{JOURNAL OF DEVELOPMENT STUDIES}

Participants - 20, represented in the government - 8; Out of proportion - 2 (7\% threshold); 7. 2008 Participants - 12, represented in the government - 5 , of which proportionally 4 ( $5 \%$ threshold); 8. 2016 Participants - 25 , of which 6 blocs with 16 entities, 5 represented in the government; Out of proportion - $3(5 \%$ threshold); 9. 2020. Participants - 50, of which 2 blocks with 7 subjects). Georgia's transition to a fully proportional electoral system will allow relatively weak and small parties to be represented in the legislature, which I think is an indicator of growing democracy and should be viewed positively.

The topic of discussion is the separation between political and civil society. Most analysts believe that the ties of Georgian political parties with specific social groups are rather weak, and they are mainly a means of pursuing the private interests of narrow groups. Jonathan Wheatley (Wheatley, 2005) believes that Georgian political parties want to enter parliament only for personal gain, lobbying for defined business interests, and seizing the necessary legislative mechanisms. "In this sense, the parties' presentation of a program based on public interests is just a curtain, which they use to convince their own people that the party really cares about them, and to show Western governments that Georgia is a democracy".

The weakness of the connection of political organizations with society is also perceived by the parties as a problem, however, they believe that it is caused by the problems in the society. A representative of one of the parties said that public interest groups are very poorly developed and it is extremely difficult to outline public order. Consequently, parties have to take political risks and decide independently when deciding on specific issues. The problem of passive citizenship, which was discussed in the chapter on society and citizenship, does not provide enough incentives for parties, and they care about the development of democracy only in cooperation with a small, active part of society. In order to define and implement effective policies, parties also need to gain practical knowledge about different social groups.

\section{References}

Chiaramonte, A., Emanuele. V. (2015). Party system volatility, regeneration and de-institutionalization in Western Europe, Sage Journals.

Crewe, I., King, A. (1994). Did Major Win? Did Kinnock Lose?

Darchashvili, M. (2020) Election Documents of Political Parties, Tbilisi.

Huntington, S. P., (1968). Political Order in Changing Societies. New Haven: Yale University Press.

Ibenskas, R., Sikk A. (2016). Mergers and splits: How party systems have changed in Central and Eastern Europe since The London School of Economics and Political Science.

Lewis, P. G. (2007). Party systems in post-communist Central Europe: Patterns of stability and consolidation, Journal Democratization.

Mainwaring, S., Scully R. Timothy (1995). Building Democratic Institutions: Party Systems in Latin America, Stanford: Stanford University Press

Mainwaring, Scott P. (1999). Rethinking Party Systems in the Third Wave of Democratization, Stanford University Press.

Molder, M. (2013). Party System Dynamics: New Tools for the Study of Party System Change and Party Transformation, Doctoral School of Political Science, Public Policy, and International Relations Central European University.

North, D. (1993). Institutions and Credible Commitment, in: Journal of Institutional and Theoretical Economics, pp. 11-23.

Organic Law of Georgia, Article 196. 2. The Parliament elected in the next parliamentary elections of Georgia shall consist of 120 members elected by the proportional system and 30 members elected by the majoritarian system. https://matsne.gov.ge/ka/document/view/1557168?publication $=65$ 


\section{JOURNAL OF DEVELOPMENT STUDIES}

Rohrschneider, R., and Whitefield, S. (2017). Critical Parties: How Parties Evaluate the Performance of Democracies, Cambridge University Press.

Wheatley J. (2005). Georgia from National Awakening to Rose Revolution: Delayed Transition in the Former Soviet Union, Ashgate Publishing Company, Burlington, pp. 158. 